\title{
Confessional and ecumenical? Revisiting Edmund Schlink on the hermeneutics of doctrine
}

D J Smit

(University of Stellenbosch)

\section{ABSTRACT \\ Confessional and ecumenical? Revisiting Edmund Schlink on the hermeneutics of doctrine}

Conrad Wethmar has always been interested in questions concerning the hermeneutics of doctrine, often concentrating on methodological issues regarding the role of confessions and the challenges of ecumenical theology. For this purpose, he consistently engaged with German-speaking Lutheran theologians. In this essay, the important views and contributions of Edmund Schlink regarding confessional and ecumenical theology are called to mind, as one further potential dialogue partner for South African theologians like Wethmar. A first section reminds readers of Wethmar's contributions. The second section recalls Schlink's theological journey and the role of confessions - both Lutheran confessions and the Confessing Church with Barmen - as well as the ecumenical church - several real dialogues between major confessional traditions, including his role during the Second Vatican Council before the third sections draws some of his major methodological insights and contributions together. A brief final section points to some potential similarities between Schlink's work and Wethmar's interests.

\section{1 “DOGMA EN VERSTAANSHORISON”?}

More than most of his contemporaries amongst South African systematic theologians, with perhaps the exception of Piet Naudé (see for example Naudé 2007), Conrad Wethmar has focused over the last two decades or more on questions of theological method and theological education (Wethmar 1997; 2003b; 2003c), especially on questions on the nature and hermeneutical function of church doctrine (Wethmar 1977; 2001; 2003a). He reflected on the nature of liberating, not restrictive orthodoxy (Wethmar 1997:424, 428; 2003a; this was already a central theme in Wethmar 1977) and on the implications for contemporary systematic theology (Wethmar 2003a). He regularly addressed questions concerning the nature and role of theology as an academic discipline within the context of the 
university (Wethmar 2003c) as well as questions concerning the identity and relevance of the church within secular and pluralist cultures (Wethmar 1990). In particular, he often discussed the confessional - in the sense of Reformed - nature of the church (Wethmar 1997; 2002) and its relation to the unity of the church (Wethmar 1993a) and ecumenical challenges (Wethmar 1993b).

For him, all these themes belong together as integral aspects of a single focus - a focus that is already to be found in his own doctoral work, on Dogma en Verstaanshorison (Wethmar 1977), on the hermeneutical nature and role of doctrine in all contemporary faith and understanding, or to put it more sharply, on the nature and role of the confessional tradition of churches in the one ecumenical Christian faith today. "(C)onfessionality and ecumenicity both play a vital role and the institutionalization of theological education should take cognisance of both" (Wethmar 1997:426).

More than most of his contemporaries amongst South African theologians, he was also one of those who most consistently engaged with European systematic theological literature, especially German theologians - according to himself, in recent years particularly Ebeling, Jüngel, Pannenberg, Moltmann (see his website). There can be no doubt that these dialogues (for his careful understanding of dialogue, see Wethmar 2001; for his views of orthodoxy as "dialogical orthodoxy", see Wethmar 1997:425) had an important impact on his own reflections, not only on his own positions, but also on the way he formulated the questions. It is for example remarkable how his dialogue with them was often influenced by the dominant Lutheran positions of most of these theologians, sometimes more than by his own Reformed tradition. This influence is also clear in his discussions of confessions, church unity and ecumenism.

For that reason, it may be an appropriate tribute to the honoree to revisit one of the most important German and Lutheran voices on these issues - on the confessional nature of the church, on church unity and ecumenism, on the hermeneutics of tradition and on orthodox faith and worship today (for the importance of prayer and worship, see Wethmar 1988; also Wethmar \& Brand 2006) - namely Edmund Schlink, amongst his own contemporaries in German theology perhaps the most consistent contributor to these questions over several decades. Wethmar has in fact himself regularly used Schlink's major contribution and most influential ideas, already since 
his doctoral thesis and still in some of his later essays (often in Wethmar 1977, for example in his central second chapter, when he discusses the development in history from confession to doctrine, and the understanding of doctrine in the tradition of the Reformation, 1977:59, 60, 94, 98-109, 115, 143; also Wethmar 1993b).

\section{REVISITING EDMUND SCHLINK}

Schlink (1903-1984) published an ecumenical systematic theology (Ökumenische Dogmatik, Schlink 1983a) shortly before his death, which remains probably the only work of its kind until today. It has not been translated into English, and in general it has not enjoyed a wide reception, in spite of positive reviews from a wide range of perspectives and several reprints. In the book, forewords by the Roman Catholic Heinrich Fries and the Orthodox Nikos Nissiotis also welcome and praise the book in glowing terms.

Through his life, however, through his active role in the life of the church, through his involvement in major ecumenical dialogues and developments, through his contributions to ecumenical meetings and activities, through his inspiration to many students, and through his deliberate reflection on ecumenical methodology, he played a remarkable role during the last century, and he has received much acclaim (including honorary degrees from the Lutheran Mainz, the Presbyterian Edinburgh and the Russian Orthodox St. Sergius in Paris).

After studying in the natural sciences, he experienced serious personal questioning of the meaning of life. He interrupted his studies and worked on a farm in Silesia where he seemed to befriend Christians in the mystical tradition of Jacob Boehme, and although he seldom spoke about it, became a deeply committed Christian through what might have been a conversion experience. He returned to Marburg and completed his doctoral studies in psychology, while also entering theological studies. After this, the centrality of the living Christ, the presence of the crucified and risen Lord would remain the characteristic of his thought, life and work. His first volumes of sermons were called Der Gekreuzigte spricht (Schlink 1934a), Der Auferstandene spricht (Schlink 1939a) and Der Erhöhte spricht (Schlink 1939b, English Schlink 1958). In later years, his office had a picture of the resurrected Christ of Matthias Grünewald's Isenheimer Altar. 
Faith meant for him a response to the gospel and theology for him is also response to the gospel. Knowledge of God results from the work of God. Theology responds to the great acts of God. Through his studies, these convictions would become stronger and more articulate and in all his theological work they would remain fundamental. The first book written on him, by the Roman Catholic scholar German Schwenzer was called Die großen Taten Gottes und die Kirche (Schwenzer 1969, on his ecclesiology) and he himself seriously considered "the mighty acts of God" as title for his dogmatics. At the heart of these great acts of God is the resurrection of the crucified Lord and his real presence through word and sacrament.

He early on studied with Karl Barth and completed his dissertation under his supervision on emotional experiences of God, in the form of an empirical-psychological contribution to the problem of natural religion. He became an active member of the Confessing Church and suffered in many ways at the hands of the state, being dismissed, refused, rejected and repeatedly unemployed. $\mathrm{He}$ regularly preached, spoke and published on Lutheran interpretations of the Barmen theses and themes and on the crises and temptations of the times facing the church. His Habilitationsschrift on Der Mensch in der Verkündigung der Kirche (Schlink 1936a) reflected convictions from Barth and Barmen. He published several lectures, papers and sermons in the new journal Evangelische Theologie (ed. by Ernst Wolf) and the new series Theologische Existenz heute (for example Schlink 1935; 1937; 1938), some of them on specific Barmen theses (for example Schlink 1936b; 1937). In 1940 he joined when Wolf and others formed the well-known Gesellschaft für Evangelische Theologie. In his Habilitations-lecture he rejected the Nazi claim that God reveals Godself in our history, in the moment, in the people's voice. "Christians should not listen to what the situation says, but to God's Word for the situation - for the hour, for the historical context, for the standpoint toward the people" (translated, Schlink 1934b). In the volume of theological essays presented to Barth on his fiftieth birthday (Schlink 1936b) he defended in similar vein the first Barmen thesis arguing from a Lutheran perspective that the activities of God as Creator are indeed hidden from our knowledge, unless we look from the perspective of faith. 
He often reflected on the nature of confession and on both the calling of the church to confess and on the challenges, dangers and temptations that accompany this calling, for example in Pflicht und Versuchung christlichen Bekenntnis (Schlink 1935), Die Gemeinde Jesu Christi und die Anfechtung (Schlink 1938), Not und Gebet (Schlink 1947e), Die Gnade in Gottes Gericht (Schlink 1946b), Der Ertrag des Kirchenkampfes (Schlink 1946a) and Nachfolge Christi (Schlink 1947c). After the War, many of these smaller documents were published as Bekennende Kirche und Welt (Schlink 1947d). In later years, he would explain that the Church Struggle brought for them "a renewed discovery of what it means to be church". It meant, amongst others, the rediscovery of the local congregation as the real church, the fact that the traditional divides in the church do not really represent the real divisions actually dividing the church, that believers are called to discernment, discipleship, witness, confession, and that the most difficult part of this, indeed the temptation, is to discern God's own activities in what is happening, God's own presence, the grace in what is experienced as divine judgment. "God not only rejected Israel because of their self-righteousness. God has since then also rejected entire churches and let them disappear. Might one not ask in a few years: Where is the evangelical church in Germany, in the land of the Reformation?" (translated, Schlink 1935). Right until the end, he would remember these experiences and insights about the church from the struggle years. "What in crisis situations in the church shines as the truth cannot in normal circumstances become untruth, even if it cannot be repeated in the same way" (translated, from his personal memories after decades, Schlink 1962:206).

This surprising rediscovery of the church in the time of the church struggle led to a critical and indeed self-critical attitude towards the church in all its forms that would remain integral to his thought and work for the rest of his life. The true church is never simply the institutional and visible church, and precisely not in its traditional divisions. Even the Confessing Church was constantly under God's judgment. To confess faith is at the same time to confess one's own guilt and one's complicity in failure, sin and evil. Confessing churches are faced with the dangerous temptation that they might see themselves as better than others, often seen in the disastrous conclusion that they may use their confession not to understand Scripture better, but in fact to measure and judge others. 
This is the theme when he speaks on the temptation hidden in Christian confession.

Damit ist christliches Bekenntnis immer zugleich Sündenbekenntnis. Bekennen, dass heißt mit dem ungläubigen Bruder, den man bittet und warnt, in voller Solidarität als Versuchter und Sünder nach Gnade schreien und Jesus Christus als einzige Rettung preisen. Wir haben im Bekenntnis keinen Maßstab, den wir nur an den anderen anzulegen brauchten, um zu messen und abzulesen, wo er irrt. Bekennen ist nicht ein Vergleichen mit anschließender Mitteilung des Vergleichensergebnisses. Der Bekennende ist nie und nimmer ein anderer als der, den er warnt, ja selbst kein anderer als der, der auf die Warnung nicht hört und das Zeugnis verschmäht. Bekenntnis ist notwendig das Eingeständnis, dass ich, der Bekennende, ohne Christus einfach nicht zurecht komme (Schlink 1947b).

In short, Christian confession is always self-critically addressed at those confessing, it is confession of solidarity in sin. It is obvious why such an attitude of self-criticism and solidarity is of extreme importance in serious ecumenical endeavors.

In this process, he was very consciously Lutheran and deliberately worked from the perspective of the Lutheran confessions, publishing a study on the Theology of the Lutheran Confessions (in German 1940; in English - Schlink 1961a) that was often reprinted and widely read and used for many years as a handbook for Lutheran studies worldwide. Some described this work as a Lutheran articulation of Barth's theology of the Word. Scripture, confession of faith and the presence of the risen Christ together form the centre of the book's argument. It very clearly underlines the importance of the Scriptural basis for the confessions and for all theological reflection in the church, a conviction that would remain characteristic of his theology through the years to follow. This Scripture proclaims the living Christ, which gave the book a deeply pastoral tone, which would remain another characteristic feature of his work through the years, sometimes remarkably so, making it impossible to distinguish his theological speeches and lectures from sermons, both directly challenging and comforting. Believers respond to this living presence of the Christ of the Scriptures by their living confession. He gives an explanation of 
the Lutheran confessions, but in his emphasis on the present and the need to be a confessing and not merely a confessional church, he sometimes sounds almost more Reformed than what many would regard as typically Lutheran. The book concludes for example with the claim - relevant for our hermeneutics and our use of confessions - that "the knowledge that the Protestant Confessions bore witness to the summary of Scripture in the face of a specific heresy of their time, leads to the recognition of what the church of the present must affirm in the interpretation of Scripture in the face of new heresies of today" (Schlink 1961a:317).

When he published this book, he described it as only the introduction or prolegomena to a dogmatics that he intended to publish soon afterwards - but it would take him another 43 years before he could eventually fulfil this undertaking. During the War he was too involved in a whole range of different pastoral contexts and tasks, in the process experiencing major personal and other crises, and after the War he remained too committed to continuous requests from the side of the church in its different forms. In his biography, Skibbe rightly comments that "throughout his career Schlink had always responded to tasks given to him by the church, rather than pursue a personal grand design for his life" (Skibbe 1999:99).

After the War, he became deeply involved in the restructuring of the Protestant Church in Germany. He was convinced that the confession of the Church - both the Lutheran tradition and the Theological Declaration of Barmen, born in the church struggle had major implications for the order of the church, and in many papers and proposals he attempted to work this out, in the end playing probably a crucial role in giving the EKD its present structure and form (e.g. Schlink 1947a). Different groups within Protestantism in Germany were faced with questions concerning their future, concerning their structure, their cooperation, their form, their unity or their lack of structural and visible unity. Amongst others, there were the so-called Council of Brethren, led by Martin Niemöller, the former leader of the Pastors' Emergency League, basically representing the groups that remained of the Confessing Church in the tradition of Barmen, there were the Lutheran territorial churches, who always resisted unity and even unified action, and wanted to form at most a united Lutheran Church in Germany in which the Lutheran Confessions would not be threatened by Barmen, and there were some overlapping groups involved in forms 
of church unification work. The conflict about the future way for the churches was deep, difficult and serious. Schlink held a lecture before the Council of Brethren called "Verkündigung und Ordnung" which he afterwards developed into a small booklet, Der Ertrag des Kirchenkampfes (Schlink 1946a). There were also alternative proposals, for example one by Hans Joachim Iwand, who objected to the suggestion that the Lutherans could first form their own unity and only then join a broader federation of different confessional churches, but eventually Schlink's ideas, that basically allowed this, because the Lutherans feared unity and unification, became the officially adopted order of the newly formed Evangelical Church.

During these years, he had always been convinced that the gospel (the great acts of God; the Scriptures; the presence of the living Jesus Christ; the confessions) does not merely have ecclesiological implications, but also ethical implications. He often wrote about ethics, he always intended that his eventual dogmatics would also include ethics, he spoke and wrote about discipleship (Schlink 1947c), but he was above all fascinated by the distinction between law and gospel (Schlink 1937; 1942; 1956; 1961b). On that point, he was deeply Lutheran and critical of Barth. He often and regularly distinguished himself from Barth over the law as form of the gospel, emphasising their differences, even in his contribution to Antwort, the Festschrift for Barth on his $70^{\text {th }}$ birthday (Schlink 1956). For him, the gospel as such makes a claim on our lives, and calls and moves us as it comforts us, but the law remains something distinct and different, serving another purpose. The law is not constructive. In the law, God is the opponent of the church, and the spiritual struggle of the church, the Anfechtung, resides precisely in the fact that the congregation must differentiate, often very concretely, between law and gospel. For him, the law is important and preaching the law is crucial. That was for him the failure during the time of the War, not merely of the German Christians, but precisely of many of those leaders and preachers who did not support Nazism themselves.

Just as great as the guilt of the political leadership is also the guilt of those church leaders and pastors, who like the false prophets of the Old Testament cried, 'God is with us,' when God had long been against us, and who proclaimed God's blessing when they should have proclaimed God's judgment, who applauded when they 
should have been silent, and who were silent when they should have given warning. They accommodated God's commandments to the totalitarian claims of political power, whose orders were proclaimed as God's orders, and whose actions as God's actions. They conferred on political acts of administering justice and waging war an arbitrary independence that was inappropriate, and they failed to measure them clearly and openly against the divine Word. I am not speaking here only of those German Christians. I think here also of the others who thought they could preach the gospel without preserving the divine law, who thought they could nurture pious inwardness, without calling publicly from the rooftops God's claim on all, and who still excused and hoped when even the stones screamed out. I think of the many whose highest principle was to preserve the church and their own office by their compromise and silence, who in secret rejected National Socialism, but wanted to preserve the church by means of their silence, when of course only God is able to preserve her, and (who) wanted through their applause to secure for the church the government's recognition, which they had to forego in that anti-Christian state (translated by Skibbe 1999:51; Schlink 1956).

Since 1946 he was appointed as professor of systematic and ecumenical theology in Heidelberg. He founded and led the wellknown Ecumenical Institute, the first such ecumenical institute in Germany. Through the following decades, many doctoral students completed their doctoral or habilitation work with him, or at least studied with him and worked as his assistants - including amongst others Reinhard Slenczka (doctoral work on Ostkirche und Ökumene; habilitation on the historical Jesus and dogmatics), Wolfgang Dietzfelbinger (Die Grenzen der Kirche nach römischkatholischer Lehre), Reinhard Neubauer (after a study visit at Princeton Theological Seminary, where he encountered Reinhold Niebuhr via Paul Lehmann), Günther Schnurr, Christoph Maczewski (on the Greek church), Viorel Mehedintu (on Orthodox dialogues), Klaus Bümlein (on Rahner), Michael Plathow (doctoral work on the concursus divinus according to Barth; habilitation on doctrine and order in the life of the church), Wolfhart Pannenberg (doctoral work 
on Duns Scotus; habilitation on analogy in Western thought up to Thomas Aquinas; working as Schlink's assistant for many years), Wilfried Joest, Adriaan Geense (Auferstehung und Offenbarung, working with Berkhof, Miskotte and Schlink), Günther Gassmann (doctoral work on the Anglican tradition; habilitation on the historical development of visions of unity in the ecumenical movement; serving as Schlink's assistant for six years), Eugene Skibbe (a Lutheran professor from Augsburg Seminary in Minneapolis, who wrote a short but very helpful biography on Schlink in English, $A$ quiet reformer, 1999, and also translated his story on the vision of the pope), and Robert Jenson (who worked with Peter Brunner as supervisor, but also thanked Schlink for presenting his work to the Faculty). Joest and Pannenberg edited a Festschrift for Schlink on his $60^{\text {th }}$ birthday, Dogma und Denkstrukturen (1963). Many of these names became well known in ecumenical circles.

For a period he served as rector of the University of Heidelberg and had the opportunity to pursue very concretely what some have called his "ecumenism of the sciences", his interest in a serious dialogue between theology and all human, social and natural sciences, together serving the truth of Jesus Christ. Already in his inaugural lecture as professor he used the scepter of the University of Heidelberg as a metaphor to argue for a particular relationship between "Christ and the faculties" (Schlink 1947f). The scepter, made in 1492, was based on a design from 1388. On the top of the staff is an open-sided cube, like a miniature room, and inside this small room the twelve-year-old Jesus sits, teaching four figures, representing the four faculties of the medieval university, namely theology, law, medicine, and philosophy. According to Schlink, this represented the vision of truth and knowledge from Bonaventure (via the first rector, who came from Paris) according to which the crucified and risen Christ is the true teacher of all the faculties. "If you do not believe, you will also not know". Convinced of the public truth of Christ, Schlink would work towards several initiatives bringing theology into ongoing and serious dialogue with other disciplines and faculties. When he became rector, he used Luther's Heidelberg Disputation, in which Luther developed the notion of a theology of the cross, to talk on "Weisheit und Torheit" (Schlink 1955). A later successor at the Ecumenical Institute, Dietrich Ritschl, would reflect on these fundamental convictions about the dialogue with the sciences, inter-disciplinary work and public truth 
in his essay on "Theologie als Erkenntnis: Edmund Schlink's Verständnis von Wahrheit” (Ritschl 1985).

Very early on he became actively involved in different forms of the growing ecumenical movement. He officially attended the meetings of the World Council of Churches in Amsterdam (1948, he gave a lecture on the church struggle; he served on a drafting subcommittee for the assembly's message), Evanston (1954, he helped plan the meeting with the Central Committee, influencing the theme; he gave one of the two opening addresses, on "Christ - the hope of the world", Schlink 1954), New Delhi (1961, where General Secretary Visser't Hooft quoted his views in a crucial speech on the calling of the WCC) and Uppsala (1968, he wrote a report on section one called "The Holy Spirit and the catholicity of the church"). $\mathrm{He}$ became a member of Faith and Order at Amsterdam and played a central role in their activities over decades (1949-1974), up to work in preparation of Baptism, Eucharist and Ministry (1982). He gave a major address before Faith and Order in Lund (1952) on "The pilgrim people of God" (Schlink 1952a).

Of crucial importance was the fact that he pleaded for the importance of all three major initiatives of the ecumenical movement at the time, namely faith and order, but also life and work and mission and evangelism (see Schlink 1972b). Already in 1935 he helped prepare the Oxford Conference on Life and Work, although all German theologians would be denied passports and could not attend. In his opening address to the Evanston Assembly, he said that hope in Christ means activity, and primarily in two forms. "The first act of hope is the preaching of the gospel to the whole world and the second act of hope is accepting responsibility for the just ordering of society" (Schlink 1954). By doing this, he explicitly provided a theological rationale for the other two major ecumenical activities. He showed his concern for the church's mission also in other ways. In Heidelberg he played the major role both in establishing a chair in missiology (where Hans-Werner Gensichen was appointed) and in founding the journal Ökumenische Rundschau for ecumenism and missiology (see e.g. Schlink 1972b; 1977b; 1978b).

His contributions were often controversial, because of his own strong convictions, born in his particular biography and experiences, and therefore in his own pastoral, often prophetic theology full of conviction and passion. The opening address during the Evanston Assembly on the assembly theme "Christ the hope of the world" 
could serve as illustration (Schlink 1954). The Central Committee was aware that there were opposing eschatologies at work in the member churches. They therefore invited both Schlink and Robert Calhoun, Professor of Historical Theology at Yale, to address the Assembly. Calhoun represented the Anglo-Saxon perspective, speaking in almost poetic style about God immanently at work in human culture and history, and of the need for activism and selfcriticism. Schlink, however, spoke in the language of New Testament imaginary, claiming that Christ is not the hope of the world in the sense of "the preservation of this threatened world." If this would be in the mind of delegates, they would "miss the point of the Assembly theme completely". He was very clear and direct. "If we expect Christ to insure this world so that people may continue undisturbed their pursuit of liberty, may carry on their business, and seek improvement in their standard of living, then Christ is not the hope of the world, but rather the end of all the world's hopes, for Christ is the end of the world. The name of Christ is taken in vain if it is used as a slogan in this world's struggle for its own preservation." The real question is how we stand in God's eyes. The real threat comes from the judgment of God, which no one can escape. The crisis is whether there is any deliverance from God's judgment. He then explains how Jesus Christ as Judge and Saviour is our hope according to the New Testament. "If hope were really alive within us, then we would know that it is not only the world which will pass away, but also the outward form of the church." American delegates and reporters were shocked and angered by his outlook, so different from their own. "North Americans tended to view Christian hope progressively, hailing efforts towards building the kingdom of God in the midst of human society" (Norman Hjelm, an American Lutheran delegate - describing the controversies as "theological fireworks not unrelated to the experiences of war"). One American delegate said angrily in the Christian Century that he had not driven 2000 miles to hear theology that he had left behind long before. The controversy remained throughout the discussions of the Assembly.

For more than three decades, from 1949 to 1979, he was at the heart of the high-level, confidential dialogue group of Lutheran and Roman Catholic theologians in Germany called the Jäger-Stählin Circle. They had regular meetings, intense discussions, read and discussed papers, addressed issues of major conflict and division between the communities and traditions, and helped in a very direct 
and lasting way to build bridges, some that would only much later become public. During these discussions Schlink himself presented several papers on controversial topics that did not become available for a long time (e.g. on "Christ and the Church: Twelve theses for an ecumenical discussion between theologians of the Evangelical and the Roman Churches", see Schlink 1957a; also in Schlink 1967a:96118). When the bodily assumption of Mary was promulgated as a new dogma, this almost led to the end of the group. Schlink was the main author of "an evangelical assessment" of the dogma, which was eventually published, and in which he offered a very strong critique, primarily based on the fact that it was not based on Scripture or the apostolic faith, supposed to be the common ground between Catholic and Protestant churches (Schlink 1950; the assessment was very favourably reviewed by T F Torrance 1951). The group, however, managed to stay together in spite of this crisis, and during 1982 and 1983 Schlink, together with Karl Lehmann, finally edited and published two well-known volumes of their papers dealing with the question whether the traditional divisions of the Reformation are still applicable, respectively on Gospel-SacramentsMinistry and the unity of the church (see Schlink 1982a) and on The sacrifice of Jesus Christ and his presence in the church (see Schlink $1983 \mathrm{~b}$ ). The early history of this group is described in Barbara Schwahn, Der Ökumenische Arbeitskreis evangelischer und katholischer Theologen von 1946 bis 1975 (Schwahn 1996). It is generally accepted that the group helped prepare the LutheranCatholic Joint Declaration on the Doctrine of Justification (see Gassmann 2004). They presented an example of long-term and difficult investment in serious academic theological work on the truly divisive issues between ecclesial communities, without any immediate results, reward or recognition.

When Pope John XXIII invited non-Roman Catholic observers to the Second Vatican Council, the Evangelical Church in Germany appointed Schlink as their representative, and in the end he became the spokesperson for all the observers and deeply involved in the activities during and around the Council (see his continuous stream of comments, reflections and studies during these years). His final reflections on the Council called Nach dem Konzil (1966, Eng. After the Council 1968). were widely acclaimed. They also showed real changes of mind on his side. In his final comments on the Amsterdam Assembly of the World Council he could still write that 
the Lutheran Church is actually at the midpoint of the ecumene (die Mitte der Ökumene), a vantage point from which he could see, measure and evaluate others on the left and right, respectively (Letters, Aug 29 1948). During the Council, this viewpoint changes, and he articulates this very deliberately and consciously in Nach dem Konzil. He rejects the attitude and expectation of many in the Roman Catholic Church that church unity could only come about if others would come back to Rome, as it were, return to the true church. Instead of ecclesiocentric approaches, he argues, Christians need Christocentric approaches. We all need to undergo a Copernican revolution, understanding that we are not the midpoint, with others circling around us in their ellipses, sometimes further away and sometimes closer. Christ is the midpoint, and we all orbit around Him, and therefore sometimes closer to one another, and sometimes farther away - with the crucial question always being how far we are, not from one another, but from Christ. In his later work on ecumenical dogmatics, this shift in perspective in the form of a Copernican revolution would provide a critical point of departure (Schlink 1983).

Schlink also became deeply involved in ecumenical relations with the Orthodox Churches, and this would increasingly move, inspire and influence him (again, see a stream of papers and contributions, for example listed in the comprehensive bibliography in Eber 1993). After the War, this involvement began in the context of the reconciliation between the Russian and German peoples. A dialogue was initiated between the German Protestant Church and the Russian Orthodox Church and Schlink was deeply moved by experiences during the preparatory visits and encounters in the Soviet Union. His respect for their faithfulness amidst difficulties and suffering led to a growing interest in Orthodox spirituality and theology. Afterwards, he wrote that he had seldom experienced in such a fundamental way, how the fellowship of faith and love breaks through the walls between confessions. These experiences, together with his friendship with Orthodox theologians and philosophers enabled him to contribute to a greater awareness to their importance within the WCC, and he in several ways helped prepare the way for the entry of the Eastern European Orthodox Churches in the World Council at New Delhi in 1961. Many believe that he enhanced the confidence of the Orthodox Churches in the WCC, for example through his very important keynote paper to the WCC's Central 
Committee in Rhodes on "The significance of Eastern and Western Traditions for the Christian Church" (1959; in Schlink 1967a:285295; for this ecumenical relationship, see Schlink 1967a:234-244; and Schlink 1967a:269-284).

On essential points the two traditions complement one another, and can warn and protect one another against the specific dangers inherent in their respective positions ... The first step must be for each of us to try to understand the importance of the other tradition ... Our first question must be what fruits of the Spirit we can perceive in other traditions, which are based on the common foundation of all churches, namely the message of the Apostles ... Our main concern must be to discover the spiritual wealth concealed in the different traditions, and to seek the unity of the church not in uniformity but in a fellowship of different traditions (Schlink 1967a:294-295).

Several of these notions, developed or strengthened through his involvement with the Orthodox Churches, became increasingly important for him, including discerning the spiritual wealth in traditions perhaps hidden behind different forms of expression, the important role of worship and liturgy as context for dogma, and the particular understanding of the unity of the church not as uniformity but rather as a fellowship of different traditions.

His insight in the important role of worship, of liturgy and prayer, became very important in his own work (for his views on music, see Schlink 1945). This conviction already grew during the experiences of the church struggle. In his sermon during the funeral of Peter Brunner he remembered how they became aware during those years of persecution "of what happens, as God promises, in worship: Christ is present" (translated, Schlink 1982b). It corresponds to Barth's views on the centrality of worship, for example in his 1938/1939 Gifford Lectures on the Scots Confession, but also in the Church Dogmatics. In Schlink's Theology of the Lutheran Confessions, the presence of Christ in preaching and sacrament was crucial. In his proposal for the reorganisation of the church in Germany, he argued that it should emerge out of the central event of worship. A major part of his leadership in reorganising the theological faculty and theological studies in Heidelberg was his initiative in forming strong links between the faculty and students and the weekly worship in the student congregation. He arranged 
that professors preach every week, establishing a practice that still continues. His first major published theological work had been on the proclamation of the church (Schlink 1936a), and out of the many ecumenical dialogues of the sixties grew his only full-length monograph on a doctrinal theme, namely The doctrine of baptism (German 1969; Eng. Translation, Schlink 1972a) - both of them dealing with the presence of Christ in the event of worship. On a more personal note, he said during the Vatican Council that he would be willing to walk back from Rome to Heidelberg to attend the worship service if Peter Brunner were to preach there. In short, from his Lutheran heritage he knew the importance of word and sacrament. During the time of the confessing church he experienced the truth, reality and power of the presence of Christ. From the Orthodox Churches he learnt the importance of worship for doctrine and therefore for a new form of ecumenical methodology (see e.g. Schlink 1967a:132-143).

Throughout all these experiences, he thought seriously as systematic theologian on the unity of the church. He often wrote on the theme, and he was involved in practical church negotiations and discussions in many ways (see e.g. Schlink 1948; 1952a; 1957a; $1969 ; 1972 \mathrm{~b} ; 1972 \mathrm{c} ; 1979 ; 1982)$. Of crucial importance was his own vision of the unity of the church. He believed both very strongly that it is a gift in Jesus Christ, already a reality, something to believe in and trust, not something for us to establish, organise or to bring about - it is the result of the compassion of Christ, the Erbarmen Christi. At the same time, however, this unity presents us with a calling to practise the unity concretely and visibly, and never to be satisfied with our disunity and divisions. His thought is documented and discussed in great detail in the dissertation by Jochen Eber with the apt title, Einheit der Kirche als dogmatisches Problem bei Edmund Schlink (Eber 1993).

He also, however, described his vision in the form of a story, called The vision of the pope (Die Vision des Papstes, 1975; translated into Spanish, Italian, French; Eng. Translation, Schlink 2001). The idea came to him during the Second Vatican Council. (The talent may be in the genes, since his son is Bernhard Schlink, the Berlin law professor and author of the best seller Der Vorleser, Eng. translation, The reader, as well as several other novels.) It was published under the pseudonym Sebastian Knecht and for eight years no-one knew who the author was, until after his death. It is a parable 
about what a truly ecumenical pope could mean for the whole church. The title is ambiguous. On the surface, it tells the story of a modern pope who, after an illness, has several visions in which Christ appears to him and speaks to him about his body. This leads him on long and remarkable journeys of ecumenical experiences and activities. On a deeper level, therefore, it is not merely about the vision that the pope had, but also about a vision of what the pope could be for the church, in today's world. The story was very well received.

One year before his death, the Ökumenische Dogmatik was finally published (Schlink 1983). It was the fruit of these many experiences and encounters, and it employed the ecumenical methodology which he had developed over the years in dealing with the different loci, especially those that are ecumenically controversial. Christoph Schwöbel, also one of his later successors at the Ecumenical Institute, describes the challenge that Schlink raises as a two-fold one: "Keine Dogmatik, die nicht ökumenisch sein sollte; aber auch: Keine Ökumene, die nicht in dem Glaubensgrund verankert ist, den die Dogmatik zur Sprache zu bringen versucht" (Schwöbel 2005:254) - no dogmatics without ecumenicity, but also no ecumenism that does not take faith and doctrine seriously.

\section{HERMENEUTICS OF TRADITION?}

During his decades of involvement in real life ecumenical dialogues and in the activities and meetings of the ecumenical movement in its different forms, Schlink made several important contributions on ecumenical methodology (see e.g. Schlink 1957b; 1966b; 1974; $1975 ; 1977 b ; 1983 b)$. Some of the early essays were eventually published in one volume, namely Der kommende Christus und die kirchliche Traditionen, 1961, (Eng. translation The Coming Christ and the coming church, 1967a, with slightly different content). In a Festschrift for his very good personal friend and colleague over many years, since the struggle and the confessing church, Peter Brunner, he reflected on "Die Aufgaben einer oekumenischen Dogmatik" (Schlink 1965). In a contribution for his former student Wilfried Joest in Kerugma und Dogma (another journal which he helped to found) he discussed "Thesen zur Methodik einer kontextuellen Theologie" (Schlink 1974). In a foundational paper for Faith and Order he wrote on "The unity and diversity of the church" (Schlink 1969). At the Ecumenical Institute at Tantur, outside Jerusalem, established by the pope after the Council, he gave a major 
lecture on "The hierarchy of truths" (Schlink 1975), a notion from the Council that he would take very seriously as ecumenical instrument. Already at Lund (1952), he was instrumental in the wellknown transition "from a comparative method to a biblicalchristologically focused method" - that would turn out to be of farreaching importance in ecumenism. He rejected ecumenical work based on "statistics," merely comparing the different viewpoints looking for "minimal consensus".

Perhaps his most important contribution, however, developing a methodology that he himself would also apply, is his essay "The structure of dogmatic statements as an ecumenical problem" (in German, Schlink 1957b; Eng translation in Schlink 1967a:16-86). This is also the essay that Wethmar would often use, already at some length in Dogma en Verstaanshorison (Wethmar 1977; again in Wethmar 1993b, where he also refers to Schlink 1983). In ecumenical gatherings we observe that members of divided churches find it much easier to pray and witness together than to formulate common dogmatic statements, he says. Members of one church have little difficulty in appropriating for themselves the prayers and preaching of members of another church. The striking fact is that they even find it possible to speak with one voice in prayer or preaching about such matters as Christology, anthropology, soteriology or ecclesiology. Why? What happens when the theological meaning expressed in prayer or preaching is transferred into doctrine?

He answers this question by describing dogmatic statements as merely one basic form of theological statement within a whole range of other basic forms of theological statements also available to faith, believers and the church. The gospel, as the message of the death and resurrection of Jesus, is the presupposition of everything - again the fundamental conviction that has been at work right through his life and thought. Believers respond to this one gospel - and they respond in different ways.

He distinguishes and analyses five basic forms of these responses, namely confession, prayer and witness, and doxology and teaching. Confession is the most basic of these forms, and it is addressed to both God and fellow human beings at the same time. Confession represents the primary act of responsive faith, claims Schlink, since in confession prayer and witness coincide in a single statement. Confession as it were takes the form of two major 
branches of responses, namely prayer directed to God and witness directed to fellow human beings. Both prayer and witness are of course rich and complex responses, with a variety of concrete and visible expressions. A very basic form of prayer is, however, doxology - since the first person speaker and the second person hearer almost disappear, and God is described in almost objective, third person language - "Glory to God in the highest". In corresponding fashion, a very basic form of witness (or testimony) is teaching, since again the first person speaker and the second person hearer almost disappear and the truth of the gospel is expressed almost in objective, third person language. Doxology (addressed to God) and doctrine (addressed to human beings) therefore correspond in remarkable ways, in spite of all their differences. Individual Christians, congregations, and churches respond to the gospel by expressing themselves in a variety of basic forms of theological statements, and it is important to keep this variety in mind and not to impoverish the response of faith by attempts to reduce them to one another in any way.

He then adds a historical perspective to this formal analysis. All these forms of faith response can change through history. Expressions that originally served as one form may change their structure and serve different purposes at later stages in history or in different contexts. He illustrates this by showing the differences between many past and present functions of dogma, in different churches, traditions and epochs - for example in the changed function of dogma between the Apostles' and Nicene Creeds (in both symbols, doxology and instruction, prayer and witness, are still united), to the shift of structure in the introductory words of the Chalcedonian Creed ("we teach, that it ought to be confessed"), to the further structural change in the Athanasian Creed ("whosoever will be saved, it is necessary that they hold"), to the Augsburg Confession ("without doubt, made in God's presence, yet it was not directed to God but to the Emperor and his contemporaries"), to the exposition of Augsburg in the Formula of Concord ("preaching progressively understood as doctrinal instruction") to the many and diverse other confessional documents of the Protestant era. In short, "the development of teaching into what we now call dogmatics has caused structural changes which have affected its contents". "Doxological statements undergo similar transformations when they 
are converted into teaching and then employed as doctrinal statements."

In short, the distinction of different basic forms of response to the gospel (of which doctrine is only one) and the awareness of the structural changes to the function of doctrine through the centuries (affecting their content) result in the fact that we cannot simply today compare the doctrinal statements of the divided churches with one another, as if they fulfil the same role in the total life of faith of the respective churches and as if they say the same irrespective of their genesis and history. In the ecumenical contact between divided churches we must consciously reckon both with the basic forms of theological statements and the (limited, albeit crucially important) place of dogmatic statements within them, and with the structural changes affecting dogmatic statements through history.

That doctrine is crucially important for Schlink is very clear. The church should guard against other forms of theological statements attaining absolute priority. If the free expression of personal prayer or the experience of being led by the Spirit dominates the believer's consciousness, then doctrine is in the danger of becoming mere description of religious experience. If doxological utterance dominates the believer's thought, doctrine becomes transformed into metaphysical ontology and history and humanity fade into the background. When liturgical and sacramental practice dominates, doctrine is reduced to introduction into the mysteries, a meditation upon and interpretation of liturgical formulas. When elementary forms of witness and the actuality of such witness attain dominance, statements about God become suspect and even impossible and God's saving history is dissolved into the actuality of present personal encounter. For him, all forms of church life and especially ecumenical approaches that are built on these kinds of preference for specific forms of faith response, thereby mistakenly detracting from doctrinal expression and formulation, are extremely problematic.

$\mathrm{He}$ is especially critical of popular claims in the Ecumenical Movement that the churches are divided because of their different and contradictory doctrinal statements, and that they should therefore rather seek to reach agreement in questions of joint moral action (life and work) performed by Christians (and others). People speaking in this way are tempted to eliminate dogmatic considerations and to declare them superfluous for unity in Christ. 
"From this point of view, dogma is the chief barrier to unity, while unity in prayer, witness and responsible action seems easy to achieve". He sees these trends, seriously threatening the work on questions of worship, doctrine, faith and order in the Ecumenical Movement "visible both in the United States and Canada and among the Younger Churches" - but he regards them as "based on a fundamental error". The root of dogma is confession, and where the church is united, this unity is essentially expressed in common confession. A church's response to the gospel which consists of prayer and witness alone is incomplete. An un-dogmatic and antidogmatic church union eventually also frustrates those communities who are hostile to dogma, since they all live according to quasidogmatic principles which operate divisively, just like those who reject tradition in principle live within the tradition of their own community and speak and act out of allegiance to it. Accordingly, "if we do not wish to trifle with dogmatic differences, we should take them seriously and strive for dogmatic unity which is essential for church unity," but by using "new methods".

The crucial question is what "unity of dogmatic expression" may mean, and his methodology is ultimately geared to deal with this question. It does not mean uniformity in dogmatic statements, in accepting the same creeds or the same dogmatic formulations. It can also consist in what he calls "mutual recognition of different dogmatic formulas" - in the way that the unity of the New Testament canon includes different kinds of witness to Jesus Christ, and the one gospel is passed on in the form of four Gospels.

This, however, makes the problem even more difficult, says Schlink. Identifying and expressing dogmatic unity, and of course identifying what could not be recognised and accepted, becomes much more difficult if the unity does not consist in uniformity, but could be hidden behind diverse forms of theological statements and behind diverse historical expressions - and when conversely the acceptance of the same doctrines, of uniformity and confessional agreement, no longer guarantees the same theological statement and the same function in the life of the church.

So, what one church community may express in one way (in worship), another church community may express in a different way (in witness, even in its ethics and life). It could therefore be very misleading if one would only compare confessions with confessions, or doctrine with doctrine. Churches may express similar convictions 
in radically different ways. On the contrary, it could lead to the discovery of unexpected agreement if one would compare different forms of theological expression with one another. We may see agreements and commonalities that we did not realise exist between divided churches - and we may of course also see the reverse, because "disunity may reign despite dogmatic agreement".

We therefore need attention to the diversity in the Biblical witness about God's great acts; a Copernican revolution in our attitudes to one another; exact philological examination of theological and doctrinal statements in their cultural contexts; exact historical investigation into the origins, developments and structural changes of theological statements; careful consideration of the anthropological presuppositions that influenced doctrinal statements; insight into the place and function of doctrinal statements within the broader range of theological responses of a particular church and tradition; analysis of the factual recognition which various statements may receive within a church (perhaps it had been important, but no longer is; perhaps it is just a historical landmark, today merely a symbol with little theological meaning); and attention to a possible hierarchy of truths. For Schlink all these tasks form part of what he calls "biblical and dogmatic hermeneutics" - of which "the problems are still underestimated".

In a way, he already used this methodology in several of his earlier papers and lectures, as well as the book on the theology of baptism, but in the ecumenical dogmatics he really delved into many controversial doctrines by making use of these assumptions. His treatment of several loci could serve to illustrate his use of this methodology, but the main implications will already be clear.

\section{CONFESSIONAL AND ECUMENICAL?}

Many of Schlink's convictions are of direct relevance for recent debates within South African Reformed circles and Wethmar will probably agree with much of what Schlink has contributed.

Firstly, Schlink's emphasis on the presence of Jesus Christ, on the resurrection of the Crucified One, on witnessing to God as the Living, Triune God is of crucial importance for many contemporary debates in these circles. It is not without reason that different ways of seeing this presence have caused major divisions and conflicts in the history of Christianity and some of the most difficult challenges 
to Christianity in South Africa today may again lie here - as Wethmar has also often indicated (Wethmar 1997:420).

Many South African Reformed theologians and believers of course also share many of Schlink's concerns and insights from the struggle of the confessing church and from his viewpoints which developed during this period on confession, the church, and the necessity of critique and self-critique in the life of the church, as well as the necessity of contextual spiritual discernment. It is not without reason that the Reformed Belhar Confession (1982/1986) originated in similar struggles, concerns and convictions.

Like Schlink, many South Africans also believe that the structuring of the real church, including its visible unity, on the basis of our confessions and theological convictions is of extreme importance. Locally, many Reformed theologians have been inspired by the claims of Barmen and Bonhoeffer that the message and the order, the truth and the visible form of the church may never be separated, which makes the structure and form of the church a theological question. Churches are still involved in ongoing and difficult discussions about this in South Africa - discussions in which Wethmar's own position may perhaps in some respects be even closer to Schlink's Lutheran thought than to traditional Reformed positions.

Furthermore, Reformed theologians, like Wethmar - and following Calvin and the confessional documents - are committed to the importance of ethics, or rather the Christian life, flowing from doctrine and theology. Wethmar has repeatedly stressed this aspect in his work on the Reformed confessional tradition (e.g. Wethmar 2002: "the combination of the faith dimensions of knowledge, experience and obedience is characteristic of the Reformed tradition"). Closely related, they are also convinced of the importance of the public church and public theology, doing and speaking in public as people who confess the Triune God, which makes the church a truth-, justice- and compassion-seeking community (slightly adapting the way in which Michael Welker, another successor of Schlink at the Ecumenical Institute, describes the positive content of the law), or, in Wethmar's words, they are convinced of the importance for the church to respond to culture and society, in the case of South Africa, a secular and pluralist society. 
Schlink regarded actual ecumenical dialogue as an extremely important calling for the church, and for him this included the different activities of the World Council of Churches, namely faith and order, life and work, mission and evangelism, as well as dialogues between the main confessional traditions. Although Wethmar has not been involved in similar ways, his valuable contributions on ecumenical methodology demonstrates his ongoing interest in the underlying issues and challenges at stake.

Many South African theologians would also wholeheartedly agree with Schlink's emphasis on hope, arguing that proclaiming and embodying hope could be seen as the real calling of the church on the continent of Africa today. For that reason, it remains instructive to see how and why the controversy of the early ecumenical movement about the nature of the Christian hope is playing itself out again in many controversies today. In fact, many would agree with Schlink's viewpoints and his criticism of the optimistic eschatology of much of American and Western cultural projects, also deeply impacting on churches in Africa, Asia and Latin America today, through the power of cultural and economic globalisation and the role of religion as integral to these global transformations.

Wethmar probably also shares Schlink's commitment to a Copernican revolution in the relationship between churches, his insight that worship, prayer and spirituality are together of crucial importance in sensing the deeper commonalities between believers, and his vision that this unity in Christ must become visible and embodied in new forms of koinonia overcoming our false divisions and differences, as well as his concern that faith, doctrine, theological reflection and serious theological dialogue must play an integral part in this process. After all, he often reflects on the importance of prayer and praise "within the logic of faith" (Wethmar \& Brand 2006; Wethmar 2003a; already Wethmar 1988) and on the nature of dialogue.

Wethmar would most certainly agree with Schlink's central claim that conscious reflection on ecumenical methodology is necessary, since it will indeed not be enough if systematic theologies are ecumenical merely in the vague way that each one eclectically reads, uses and ignores whatever they prefer, but rather ecumenical in a specific and real, rich and complex way. What is needed is what another German and Lutheran theologian, Bernd Oberdorfer, in a 
persuasive argument describes as ecumenical dogmatics "in einem gefüllten Sinn" (Oberdorfer 2008).

Finally, Wethmar would certainly appreciate Schlink's insistence that ecumenical theology should be done consciously from the perspective of one's own tradition and community, and probably even that a dogmatics from and for one's own perspective could serve as prolegomena for real ecumenical engagement. In short, like few others, Schlink practised what Wethmar so often argued for, namely a form of theology that is both confessional and ecumenical at the same time - perhaps an early version of the "ecumenism of profiles" that the leading Protestant and ecumenical theologian and church leader Wolfgang Huber is making popular at the moment - "(Eine) doppelte Wahrnehmung der erreichten Nähe und der bleibenden Unterschiedlichkeit gehört zur Wahrhaftigkeit in unserer Situation" (Huber 2008:1).

\section{Consulted literature}

Eber, J 1993. Einheit der Kirche als dogmatisches Problem bei Edmund Schlink (Forschungen zur systematischen und ökumenischen Theologie. Band 67). Göttingen: Vandenhoeck \& Ruprecht.

Gassmann, G 2004. Edmund Schlink - An ecumenical pioneer of the $20^{\text {th }}$ century. Ecumenical Trends 33(1), 6-10.

Huber, W 2008. Ökumene der Profile. http://www.uni-bamberg.de/fileadmin/uni/ fakultaeten/ppp_lehrstuehle/ evangelische theologie_1

Joest, W \& Pannenberg, W (Hrsg.) 1963. Dogma und Denkstrukturen. Festschrift für Edmund Schlink. Göttingen: Vandenhoeck \& Ruprecht.

Naudé, P J 2007. Reformed confessions as hermeneutical problem, in Alston W \& Welker M (eds), Reformed Theology. Identity and Ecumenicity II, Grand Rapids, Mi: Wm B Eerdmans, 242-260.

Oberdorfer, B 2008. Ökumenische Dogmatik? ÖR (forthcoming).

Ritschl, D 1985. Theologie als Erkenntnis: Edmund Schlinks Verständnis von Wahrheit vor dem Hintergrund der Theologen seiner Generation. ÖR 34, 287-298.

Schlink, E 1934a. Der Gekreuzigte spricht. Berlin: Furche.

-, 1934b. Die Frage der Erkennbarkeit göttlichen Handelns in der Geschichte. Ev Th 1, 257-277.

-, 1935. Pflicht und Versuchung christlichen Bekennens (Theologische Existenz heute. Heft 20). München: Kaiser.

-, 1936a. Der Mensch in der Verkündigung der Kirche. Eine dogmatische Untersuchung. München: Chr. Kaiser. 
1936b. Die Verborgenheit Gottes des Schöpfers nach lutherischer Lehre. Ein Beispiel zum lutherischen Verständnis der ersten Barmer These, in Theologische Aufsätze Karl Barth zum 50. Geburtstag, München: Kaiser, 202-221.

-, 1937. Gesetz und Evangelium: Ein Beitrag zum lutherischen Verständnis der 2. Barmer These (Theologische Existenz heute. Heft 53). München: Chr. Kaiser.

-, 1938 Die Gemeinde Jesu Christi und die Anfechtung (Theologische Existenz heute. Heft 59). München: Kaiser.

-, 1939a Der Auferstandene spricht. Berlin: Furche.

-, 1939b Der Erhöhte spricht. Berlin: Furche.

-, 1942. Gottesebenbild als Gesetz und Evangelium, in Der alte und der neue Mensch, München: Lempp, 68-87.

-, 1945. Zum theologischen Problem der Musik. Tübingen: J.C.B. Mohr.

-, 1946a. Der Ertrag des Kirchenkampfes. Gütersloh: C. Bertelsmann.

-, 1946b. Die Gnade in Gottes Gericht. Gütersloh: C. Bertelsmann.

-, 1947a. Gedanken zur Ordnung der Evangelischen Kirche in Deutschland. Stuttgart: Evangelische Gesellschaft.

-, 1947b. Die Versuchungsstunde der bekennenden Kirche. Stuttgart: Evangelische Gesellschaft.

-, 1947c. Nachfolge Christi. Drei Gemeinde-Vorträge. Bielefeld: Ludwig Bechauf.

-, 1947d. Bekennende Kirche und Welt. Vorträge und Predigten aus den Jahren 1934 bis 1945 (Das Christliche Deutschland). Tübingen: Furche.

-, 1947e. Not und Gebet. Tübingen: Furche.

-, 1947f. Das Szepter der Universität Heidelberg: Christus und die Fakultäten, in Aus Leben und Forschung der Universität 1947/1948, Hg. W Kunkel. Heidelberg: Springer, 31-50.

-, 1948. The church and the churches. Ecumenical Review 1, 150-168.

-, 1950. Evangelisches Gutachten zur Dogmatisierung der leiblichen Himmelfahrt Mariens. München: Chr. Kaiser.

-, 1951. The nature of the Christian hope. Ecumenical Review 4, 284-290.

-, 1952a. The pilgrim people of God. Ecumenical Review 5, 27-36.

-, 1952b. Gerechtigkeit und Gnade. KuD 2, 256-288.

-, 1953. The Christian hope and the unity of the church. Ecumenical Review 6 , 113-117.

-, 1954. Christ - the Hope of the World. Ecumenical Review 7, 127-139.

-, 1955. Weisheit und Torheit. KuD 1, 1-22.

-, 1956. Gesetz und Paraklese, in Antwort. FS zum siebzigsten Geburtstag von Karl Barth am 10. Mai 1956. Zürich: Zollikon, 323-335. 
-, 1957a. Christ and the Church. Scottish Journal of Theology 10, 1-23.

-, 1957b. Die Struktur der dogmatischen Aussage als ökumenisches Problem. KuD 3, 251-306.

-, 1958. The Victor speaks. St. Louis, MI: Concordia.

-, 1961a. Theology of the Lutheran Confessions (German, 1940). Philadelphia: Fortress.

-, 1961b. Gesetz und Evangelium als kontroverstheologisches Problem. KuD 7, 1-35.

-, 1962. Persönlicher Beitrag, in: Männer der Ev. Kirche in Deutschland: FSf. Kurt Schaf zu seinem 60. Geburtstag, Hg. H Vogel. Berlin: Lettner, 206-207.

-, 1963. Die biblische Lehre vom Ebenbild Gottes, Pro Veritate: Ein theologischer Dialog. Kassel: Stauda, 1-23.

-, 1965. Die Aufgabe einer ökumenischen Dogmatik, in Zur Auferbauung des Leibes Christi: FS Prof. D. Peter Brunner zum 65. Geburtstag, Kassel: Stauda, 84-93.

-, 1966a. Nach dem Konzil. München: Siebenstern.

-, 1966b. Die Methode des dogmatischen ökumenischen Dialogs. KuD 12, 205-211.

-, 1967a. The coming Christ and the coming church. London: Oliver and Boyd.

-, 1967b. Über die Befreiung der Kirchen zum Dienst an der Welt, Kirche und Staat: FSf. Bischof D. Hermann Kunst, Berlin: De Gruyter, 134-149.

-, 1969. Unity and diversity of the church, in What unity implies, Geneva: WCC, 33-51.

-, 1971. Zum ekklesiologischen Dialog zwischen römisch-kathlischer und evangelischer Theologie. ThLZ 96/8, 561-568.

-, 1972a. The doctrine of baptism. St. Louis, MI: Concordia.

-, 1972b. Die Bedeutung von 'Faith and Order' für die ökumenische Bewegung und die Evangelische Kirche in Deutschland. ÖR 21, 145-159.

-, 1972c. The unity of the church and differences in culture. One in Christ 4, 356-375.

-, 1972d. Zur Unterscheidung von ius divinum und ius humanum, in Begegnung: Beiträge zu einer Hermeneutik des theologischen Gesprächs. Köln: Styria, 233-249.

-, 1974. Thesen zur Methodik einer kontextuellen Theologie. KuD 20, 87-90.

-, 1975. Die 'Hierarchie der Wahrheiten' und die Einigung der Kirchen. KuD 21, 1-12.

-, 1977a. Die drei Grundbeziehungen zwischen Glauben und Erkennen. KuD 23, 172-187. 
-, 1977b. Theologische Sprachanalytik im Vorfeld der ökumenischen Fragestellung. ÖR 26, 63-73.

-, 1978a. Gottes Handeln durch die Taufe als ökumenisches Problem. KuD 24, 164-180.

-, 1978b. Rechenschaft über die ökumenische Hoffnung. ÖR 27, 352-358.

-, 1979. Die ökumenische Charakter und Anspruch des Augsburgerischen Bekenntnisses, in Augsburgische Konfession im ökumenischen Kontext, Hg. H. Meyer. Stuttgart: LWF, 1-28.

-, 1982a. Kriterien der Einheit der Kirche aufgrund der Augsburgischen Konfession, in Evangelium - Sakramente - Amt und Einheit der Kirche, Hg. K. Lehmann \& E. Schlink, Göttingen: Vandenhoeck \& Ruprecht, 109-121.

-, 1982b. Predigt in der Trauerfeier für D. Peter Brunner. KuD 28, 2-6.

-, 1983a. Ökumenische Dogmatik: Grundzüge. Göttingen: Vandenhoeck \& Ruprecht.

-, 1983b. Struktur und Rangordnung der dogmatischen Aussagen über das Herrenmahl, in: Das Opfer Jesu Christi und seine Gegenwart in der Kirche, Hg. K. Lehmann \& E. Schlink, Göttingen: Vandenhoeck \& Ruprecht, 138175.

-, 2001. The vision of the pope. A narrative (transl. by Eugene M Skibbe). Minneapolis: Kirk House.

Schwahn, B 1996. Der Ökumenische Arbeitskreis evangelischer und katholischer Theologen von 1964 bis 1975. Göttingen: Vandenhoeck \& Ruprecht.

Schwenzer, G 1969. Die grossen Taten Gottes und die Kirche. Paderborn: Bonifacius.

Schwöbel, C 2005. Edmund Schlink - Ökumenische Dogmatik, in: Wegbereiter der Ökumene im 20. Jahrhundert, Hrsg. C Möller u.a., Göttingen: Vandenhoeck \& Ruprecht, 232-254.

Skibbe, E M 1999. A quiet reformer. Minneapolis: Kirk House.

Torrance, T F 1951. Review, Evangelisches Gutachten. Scottish Journal of Theology 1951/4, 90-96.

Wethmar, C J 1977. Dogma en verstaanshorison. Amsterdam: Rodopi.

-, 1988. Godsleer en gebed, in Wethmar, C J \& Vos, C J A (reds), ' $n$ Woord op sy tyd, Pretoria: NGKB, 217-237.

-, 1990. Teologie en samelewing, in Kuitert, H M et al (reds), Cultuur als partner van de theologie, Kampen: J H Kok, 24-41.

-, 1993a. Die ekumeniese roeping van die kerk in die lig van die Gereformeerde belydenisskrifte, in Crafford, D \& Gous, G (reds), Een liggaam - baie lede, Pretoria: Verba Vitae, 37-43.

-, 1993b. Ekumenisiteit in dogmatologiese perspektief, in Crafford, D \& Gous, G (reds), Een liggaam - baie lede, Pretoria: Verba Vitae, 44-55. 
-, 1997. Ecclesiology and theological education: A South African reformed perspective. Skrif en Kerk 18(2), 415-430.

-, 2001. Doctrine and dialogue, paper proposal for the Leuven Encounter in Systematic Theology III, http://www.theo.kuleuven.be/lest

-, 2002. Die NG Kerk en Gereformeerdheid: Gestalte en uitdagings. Verbum et Ecclesia 23(1), 250-256.

-, 2003a. Die "Nuwe Hervorming" en die Ortodoksie. Verbum et Ecclesia 24(2), 644-649.

-, 2003b. Theological education in an ecumenical context: Principles and procedures of the Pretoria model, in Brinkman M E et al (eds), Theology between church, university, and society (Studies in Theology and Religion, STAR 6), Assen: Royal van Gorcum.

-, 2003c. Theology between church, university and society, in Brinkman M E et al (eds) Theology between church, university, and society (Studies in Theology and Religion, STAR 6), Assen: Royal van Gorcum.

Wethmar, C J \& Brand, S J P 2006. Die logika van die geloof: gebed as raakpunt tussen rasionaliteit en ervaring by Rahner en Calvyn. NGTT 47(3) $\& 4,799-816$. 